Historic, Archive Document

Do not assume content reflects current scientific knowledge, policies, or practices. 



\section{... Introduction ...}

In presenting to you this catalogue we are trying to tell you about our flowers in the same language we would use if we had the pleasure of meeting you in our garden.

As we consult our Garden Notes, we again see the flowers in all their glory, as they were all through the summer.

Were we to choose a few "best" glads we would not know how to proceed, yet there are a few which stand out and above the glorious mass of blooms.

Mother Machree, of course, is a thing apart, being so different and exclusive: A spike of Marmora is a gorgeous thing, with Emile Auburn they make a fine team. Mrs. S. A. Errey, a beautiful orange tone with a deep blotch is a very fine exhibition variety. Minuet, in our estimation, is still the best lavender, and as near perfect as any glad. Berty Snow is preferred by some, as is also Dr. Moody.

To Pearl of California belongs the softest spot in our heart. Betty Nuthall is in a fair way to conquer the glad world; to see her is to love her. The French variety, Paul Deschanel, is another fine flower. The fiery orange of LaPaloma invariably drew every visitor.

Which is the best yellow? Well, it is very hard to say, but here are Gold Eagle, Canberra, Golden Dream, Loyalty, Tobersun, Golden Frills, Primrose Princess, The Grand Guardian and the dainty little primulinus species, the Maid of the Mist.

The whites are well represented with Helen Wills, Mrs. F. C. Hornberger, Mammoth White, Purest of All.

Groff's Rose Dream will surely be heard from, and Salbach's Pink will make its mark.

In a corner of the garden Charles Dickens, tall and bright, is flirting with his darker neighbor, Chateau-Margaux; a new "entente cordiale" perhaps?

Who shall say which is the best "blue"? We are quite partial to Veilchenblau of the large, well open flower and deeper color. Geraldine Farrar is quite exquisite. Heavenly Blue is delicately beautiful, and Mrs. van Konynenburg has more color.

Reds in profusion, all good, and if you like a bright red, Dr. F. E. Bennett will set your garden on fire; but, I beg of you, do not plant it alongside of Purple Glory. Pfitzer's Triumph is still the "Triumph" it has always been.

And, among the throng of garden guests, Conchita and Georgette timidly raise their pretty heads, for all the world like two young debutantes.

But the flowers are now all gone. The fields are bare. In the bulb house the screen bottom trays are full of plump high crowned bulbs; each tray, neatly labeled with the names which remind us of the glories of the past season; each bulb containing a promise for the coming season.

If you are not interested in this catalogue, please do not destroy it, but hand it to a friend who loves flowers.

We thank you.

MR. AND MRS. W. H. KINGSLEY. 


\section{... Gladiolus the Beautiful...}

When, in 1855, Queen Victoria visited Napoleon III at Fontainebleau, little did she know that the beautiful gladiolus, which she so much admired in the French Emperor's garden, were but the beginning of the procession of beauty that was to come.

Now, after seventy odd years, through the efforts of breeders in two continents, there are Gladiolus in many forms and shapes, and no other flower comes in such a variety of colors; from the purest white to the deep yellows and warm buffs, the vivid oranges and scarlets, the most delicate pinks, the bright reds and deep velvety maroons, the soft rose and rich purples, the lavender blues, also the "smoky" shades, which generally consist of a bright color overlaid with a greyish veil; imagine a bright sunset seen through a fleecy cloud.

If, perchance, you have never grown Gladiolus, a world of pleasant surprise awaits you this summer when your "glads" begin to bloom and unfold their hidden treasures.

Those of you who are already "Glad Fans" will be interested from the moment you put your bulbs in the brown earth; you will patiently care for your plants and wait for the glorious blooms, knowing that you will not be disappointed; always there will be new forms, new colors, new combinations, unexpected arrangement of markings, in the varieties that will bloom in your garden for the first time, while the older varieties, those that you have known for several seasons, will be looking at you like old friends with an ever new beauty, bravely competing for your favors with your new acquisitions.

The Gladiolus are so regal in their beauty that they grace the costliest gardens, and so democratic in their demands that the novice cannot fail to reap a wealth of flowers from his planting.

As a garden flower the Gladiolus are unsurpassed; they are superb for a garden border, for their long spikes are dressed in glorious colors; in groups among the shrubbery, where there is plenty of sunshine they make a wonderful picture.

A group should be of six or more of one variety or of one color group, and is within the means of even those who have only a limited space for their culture.

Fine as they are for the garden, Gladiolus are in all their glory as cut flowers. The purposes for which they can be used are endless; from the tall large vase or basket for the living room, to the dainty corsage bouquet of one single bloom, bowl for the dining room table or single spike for the slender vase; the florists use them in profusion for bridal bouquets and the sick enjoy them all the more because they have no cloying perfume.

Every garden should have, at least, a few of these; they are easy to grow and give more pleasure for the amount of work involved than any other flower.

Among that array of beauty several different types of Gladiolus are now recognized by the American Gladiolus Society; the exhibition type usually has a long spike, with large, well open individual flowers of a beautiful coloring, and many open at the same time.

The Commercial type is the kind the florists prefer, mostly in light colors, beautiful in mass, the flowers of heavy substance and not quite so large, so that they are not so fragile; here we sacrifice beauty to usefulness. The Landscape type consists of shorter, stocky plants that have more resistance to the wind, of a pleasing color that does not fade in the suin, but the form need not be so perfect.

The crossing of these types with the little yellow Gladiolus Primulinus, the "Maid of the Mist," has produced an entirely different race of Gladiolus with slender willowy spikes, smaller flowers, mostly hooded like their wild parent, artistically placed on the stem; the colors are softer and delicately blended, there are white, yellows, many shades of buff and orange, pale pinks, rose colors and even lavenders and orchid; there is red also, but even the bright reds are softer than in the larger or grandiflora types. These primulinus hybrids are unexcelled for home decoration and, being very floriferous, are also very good for the garden. 


\section{... Read This Carefully... .}

All the varieties in this catalogue have been thoroughly tested and tried and are the best obtainable.

Each year we try the new ones and retain those which show advancement over the older varieties.

It is impossible to grow all the good glads, so we have to discard a few each year to make room for the newer ones,

IVe guarantee all stock to be true to name.

We cannot guarantee results, as growing conditions are beyond our control, but send out only vigorous, healthy bulbs.

\section{About Our Discounts}

We have originated a system of discounts which, we believe, is fair to all: We give you a discount on a sliding scale, the larger your order the greater your percentage of discount.

We give you a discount of $1 \%$ for every dollar of your order, up to $25 \%$ for instance:

When your order amounts to $\$ 5.10$ you may deduct 5 cents on each dollar, or 25 cents; if your order is $\$ 8.00$ you may deduct 8 cents on each dollar, or 64 cents.

When your order reaches $\$ 25.00$ or over you may deduct $25 \%$, or 25 cents on each dollar for the whole amount of the order.

Club your orders with your friends and neighbors and get the greater discount.

All orders will receive careful attention and will be filled to your satisfaction; we do not promise the Earth, but we promise to please you.

Each season our business more than doubles; there is a reason for such growth-satisfied customers are our greatest asset.

\section{About Prices}

Prices in this catalogue supersede all prices in previous lists. The prices of the different varieties are as low as is consistent with good, well grown stock and selected bulbs. Prices are per each bulb, twelve bulbs of one variety for ten times the price of one. No item of bulblets sold for less than $\$ 1.00$

\section{About Sizes}

Commercially the Gladiolus is divided into six sizes: No. 1 is over

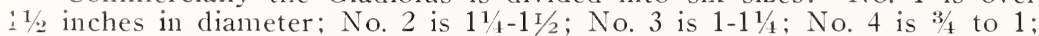
No. 5 is $1 / 2-3 / 4$; No. 6 to below $1 / 2$ inch. For retail trade Nos. 1 and 2 are called large by most growers and No. 3 medium. These are my sizes. But a few growers call No. 3 large and Nos, 4 and 5 medium. Such growers can make very low prices. Be sure what size the grower is offering for the money.

Send us your order early, the stock of some of the best varieties is very iimited. If out of a certain variety we will not substitute unless asked to do so, but we will, when out of large bulbs, fill your order with double the amount in smaller size of same variety.

Full cultural directions included with every shipment. Cash should accompany all orders.

Remittance should be made by Post Office Money Order, Express Money Order or Bank Draft.

All retail orders will be delivered prepaid to all points reached by Parcel Post. No orders of less than $\$ 1.00$ accepted.

Please write your name and address very plainly.

Prices quoted and orders accepted subject to prior sale.

References: Bank of Hayward, Hayward, California.

\section{TO REACH OUR PLACE}

When in Hayward, take the Hayward-San Mateo Bay Bridge Highway (Jackson Street) one mile to the S. P. R. R. crossing, where you will see our sign, from there on, follow our signs.

From San Francisco, or the San Mateo side, drive through Mt. Eden straight ahead until you come to the same S. P. R. R. crossing, and follow our signs. 


\section{... New Kingsley Originations ...}

We are offering for the first time two new varieties which, we believe, will be a worthy addition to any collection.

Conchita (Seedling No. 15-3). A tall plant with a straight spike. The upper hall of the flower is light Venetian pink, lower petals cream, bordered Venetian pink. 18 florets to the main spike and about the same amount on laterals, 6-7 medium size flowers open at the same time and well placed. Just enough Prim. blood in it to make it graceful. Vigorous grower and good propagator.

Bulbs, any size, each $\$ 2.00$. No bulblets.

Georgette (Seedling No. 26-2). A clear geranium pink flower daintily ruffled. Lower petals have a fan shaped begonia rose marking on a cream blotch. Plant medium height, spike straight, flowers of good size and substance and well placed. 20-22 florets to the spike, 4 open at the same time. The coloring is exquisite, the flower very attractive and the keeping qualities excellent. Bulbs, any size, each $\$ 5.00$. No bulblets this season.

\section{... General List. . .}

Aflame (Hornberger). Begonia rose shading to bright orange flame near the edge. Back of petals is even brighter. Very large, six inches or more across. Six or more flowers open. A wonderful variety and by far the largest of the Prim. Grand.

Large, \$1.00; Medium, 60c; Small, 30c.

Allen V. Bunce (Bill). A tall Prim. hybrid of good size. Vivid orange flowers with deeper marking. Quite early.

Large, 25c; Medium, 15c; Small, 10c; Blts., 25 for $\$ 1.00$.

Apricot Glow (Palmer). Soft Apricot buff. An exquisite new prim with an open face. Won several prizes last summer at the leading glad shows.

Large, 50c; Medium, 30c; Small, 10c; Blts., 25 for $\$ 1.00$.

Annie Laurie (Brozen). Ruffled delicate pink overlaid with light rose pink toward the edge. Light carmine lines in the throat. Very dainty and beautiful.

Large, 20c; Medium, 10c.

Beauty Wave (Kunderd). An attractive ruffled yellow, tinted pink. Large, 25c; Medium, 15c; Small, 10c; Blts., 25 for $\$ 1.00$.

Betty Joy $(B i l l)$. Soft creamy white flushed La France pink. Strong grower, long flower spikes with 6 to 10 perfect flowers opening at a time. Delicately beautiful.

Large, 25c; Medium, 15c; Small, 10c.

Betty Nuthall (Salbach). Large blooms of a warm light coral color; with pale orange throat markings and feathering of carmine. Spikes long and graceful with six to eight blooms open at once. In our opinion this is the best of Mr. Salbach's originations and he has some mighty good ones.

Large, \$4.00; Medium, \$2.50; Small, \$1.25.

California $(K c h f$.$) . A tall, massive spike of orange colored bloom. Very strik-$ ing and beautiful.

Large, \$1.00; Medium, 75c; Small, 50c.

Campanile (Kingsley). A tall Prim. hybrid of very good form. Flowers salmon color, buff yellow throat with faint carmine lines. Seven flowers open at the same time and one of the tallest growers in the garden. A lovely cut flower, and fine for baskets

Large, 25c; Medium, 15c; Small, 10c.

Canberra (Erry Bros.). A very large striking pure deep yellow self. Tall strong spikes with eight or more florets open. Awarded first prize as the tallest spike at the 1929 show at the Palace Hotel, San Francisco.

Large, $\$ 1.50$; Blts., 10 for $\$ 1.00$.

Cardinal Prince (Kunderd). Fine self-colored cardinal red, with good sized blooms well placed on strong but graceful spike. A really good red. Large, 15c; Medium, 10c.

Carolus Clusius (Velthuys). Beautiful light rose pink. Several well placed blooms open at a time. Should be a fine commercial flower. Large, \$1.00; Medium, 50c; Small, 35c; Blts., 25 for $\$ 1.00$. 
Catherine Coleman (Colcman). Very large geranium pink. Excellent substance. fine placement, long spikes. One of the aristocrats.

L,arge, 25c: Medium, 15c: Small, 10c.

Chardonneret (Vilmorin). A French primulinus of a lilac rose color with crimson carmine flecking. Unusual coloring. Plant vigorous and flower quite large.

Large, $\$ 1.00$; Medium, 50c; Small, 25c; B1ts., 15 for $\$ 1.00$.

Charles Dickens (Pfitzer). A bright purple flower on a tall straight spike, very attractive and showy.

Large, 50c; Nedium, 35c; Small, 25c; B1ts., 20 for $\$ 1.00$.

Chateau-Margaux (Kingsley). Spike tall and slender, flowers of that velvety shade of dahlia purple so popular this season. Several well placed flowers open at the same time. Blends beautifully with the brighter Chas. Dickens. Large, 50c; Medium, 35c; Small, 25c; B1ts., 20 for $\$ 1.00$.

Chicago (Kunderd). A deep geranium red ruffled flower, all petals bordered with a narrow bluish line; lower petals feathered deeper red. A magnificent flower and different from any other glad.

Large, \$2.00; Medium, \$1.00; Small, 75c; Blts., 10 for $\$ 1.00$.

Copper Bronze (Kunderd). The name describes the color. A very unusual primulinus hybrid.

Large, 25c; Medium, 15c.

Coryphee $(P$ fitier $)$. A very light pink flower with a white throat. A very beautiful flower of excellent substance.

Large, 2.50; Medium, $\$ 1.50$; Small, $\$ 1.00 ;$ B1ts., 10 for $\$ 1.00$.

Del Oro (Burbank). Fine deep orange flower with a golden yellow throat. Very good.

Large, 25c; Medium, 15c.

Del Rosa (Burbank). Large, wide open flower of a bright scarlet color with a big creamy white blotch. Very similar to the popular Australian variety Victor. This and Del Oro are extra good landscape glads.

Large, 25c; Medium, 15c.

Dr. Crist Martz (Kunderd). A beautiful light blood red flower with ruffled petals. Very showy.

Large, 25c; Medium, 15c.

Dr. F. E. Bennett (Diener). Peach-red, overlaid with flame-scarlet, throat speckled with ruby and white. A very attractive large red, with plenty of vigor.

Large, $15 \mathrm{c}$.

Dr. Moody (Kinyon). A new lavender of promise, good strong grower and very prolific. Very fine as a cut flower and should be a good commercial variety. Has won many prizes.

Large, $\$ 1.25$; Medium, 75c; Small, 50c; Blts., 25 for $\$ 1.00$.

Dr. Nelson Shook (Kunderd). Deep Tyrian rose lighter in the throat. Ruffled petals, and a beauty.

Large, 50c; Medium, 35c; Snall, 20c; B1ts., 35 for $\$ 1.00$.

Emile Aubrun (Lemoine). A very large, wide open French variety. The blooms are in the fuchsia shades with a gray overtone. A Tyrian rose blotch on the lower petals with a halo of scarlet, glows like molten lava. Tall and vigorous. A most unusual and fascinating flower.

Large, 25c; Medium, 15c; Small, 10c; B1ts., 50 for $\$ 1.00$.

Frank M. Shick (Salbach). A geranium pink flower with soft cream throat markings, 8 to 10 well placed blooms open. A good grower and very prolific. Large, $\$ 1.00$; Medium, 50c; Small, 25c; Blts., 20 for $\$ 1.00$.

Frederick Christ (Diener). Very large flowers of a delicate La France pink with canary throat. Long flower spike with many open. Large, \$3.00; Medium, \$2.00; Small, \$1.00; B1ts., 10 for $\$ 1.00$.

Fulds Favorite (Kunderd). Light lavender rose flower with lighter throat. Many flowers open and very good placement. Large, 50c; Medium, 35c; Small, 20c; Blts., 20 for $\$ 1.00$.

Gay Hussar (Salbach). Large, wide open flower of rich salmon orange, light orange yellow blotch with scarlet markings. A very fine flower and rapid multiplier.

Large, \$1.50; Medium, \$1.00; Small, 50c; B1ts., 15 for $\$ 1.00$.

Geraldine Farrar (Diencr). Pale lavender-violet with deep violet spot on the lip. One of the best of this color. Always in great demand.

Large, 25c: Medium, 15c. 


\section{A Few Money Makers For The Trade}

PREPAID BULB PRICES PER HUNDRED

25 AT THE HUNDRED RATE

No. 1 No. 2 No. 3 No. 4 No. 5 No. 6

BULBLETS

Betty Nuthall____\$100.00 $90.00 \quad 80.00 \quad 70.00 \quad 50.00 \quad 30.00$ Per $100, \quad 5.00-1000,27.00$

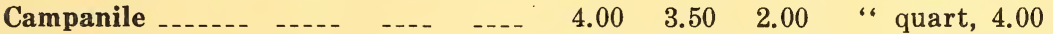

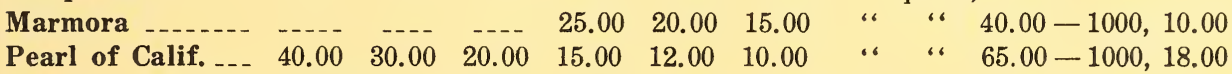

We will quote you special prices on lots of 500 to 5000 on planting stock of any of the above varieties. Bulblets by the quart, peck or bushel.

Terms Cash With Order. 


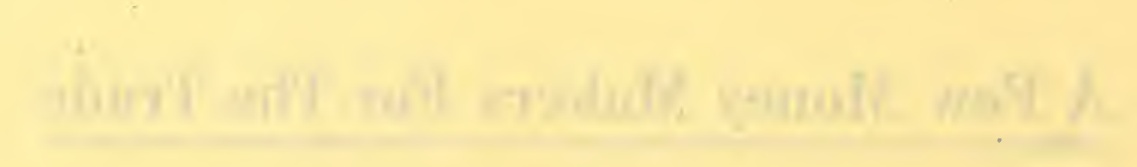


Gertrude Errey (Errey). Light salmon pink at the edge of the petals shading off to nearly white at the throat, crimson feather on lower petals. Gracefully formed flowers on good long spike. Very refined.

Large, 25c; Medium, 15c; Blts., 25 for $\$ 1.00$.

Gladdie Boy (Bill). Primulinus Grandiflorus type. Flowers well expanded with only a slight hooded effect. The color is very distinctive, the general effect being a grenadine pink blending with straw yellow deep in the center.

Large, 25c; Mediun, 15c.

Gloriana (Betscher) A golden salmon flower with a clear yellow throat. The most beautiful color imaginable. The plant is tall, the flowers do not open very wide, but have a very distinctive shape.

Large, $25 \mathrm{c}$.

Gold Eagle (Austin). A real deep yellow. A vigorous grower very early. The lovely clear color does not burn, fade or fleck in the hottest sun. This past season we discovered that after cutting the flowers on the large size bulbs, a majority of the plants threw up another spike, started very low, and large enough for bouquets, giving a second season of bloom.

Large, 20c; Medium, 15c; Small, 10c; B1ts., 100 for $\$ 1.00$.

Golden Dream (Groff). Fine, clear, deep yellow, with several flowers open on a tall, straight spike. A very fine outstanding variety. Late.

Large, 40c; Medium, 30c; Small, 15c; B1ts., 50 for $\$ 1.00$.

Golden Frills ( Kunderd). An exceptionally fine Prim. hybrid of clear daffodil yellow with deep pink lines on lower petals. Intensely ruffled and very choice.

Large, 25c; Medium, 15c; Small, 10c; B1ts., 50 for $\$ 1.00$.

Golden Orange (Kunderd). A Primulinus Grandiflorus of a beautiful soft orange tone. Good size flower perfectly placed on a tall spike.

Large, 50c; Medium, 35c; Small, 20c; B1ts., 25 for $\$ 1.00$.

Heavenly Blue (Pfiticr). Soft lavender blue, a little lighter than Mrs. -Van Konynenburg. Very tall, straight spike with many blooms open at same time. Blooms freely from bulblets. In great demand and very scarce. Large, \$1.00; Medium, 60c; Small, 40c; B1ts., 20 for $\$ 1.00$.

Helen Wills (Salbach). A very elegant, clean, large white flower shading to soft canary on lower petals. Tall, vigorous and of wonderful substance. Large, 75c; Medium, 50c; Small, 25c; B1ts., 50 for $\$ 1.00$.

Herbstzauber $(P$ fitzer $)$. Large round flowers of a beautiful orange red color with a deeper blotch. One of the parents of Pfitzer's Triumph. Quite late. Small, 15c.

John Toland (Salbach). Massive spike of very large bold flowers. Peach red shading lighter to center, prominent velvety ox-blood blotch on lower petals, five to six open at once.

Large, 50c; Medium, 25c; Small, 15c; B1ts., 25 for $\$ 1.00$.

King Tut (J.C. Davis). A large flower of salmon pink blending into peach red, fine throat markings. This variety has a strong tendency to doubling; we have had florets with as many as 14 petals. Very interesting.

Large, $\$ 2.00$; Blts., 10 for $\$ 1.00$.

New Violet (Kirch.) An improvement on Kirchhoff's old Violet. More vigorous and a good propagator. One of the best of the dark violets. Large, 25c; Medium, 15c; B1ts., 50 for $\$ 1.00$.

Kunderd, A. E. (Kunderd). A very strongly ruffled variety. In color salmon rose, lighter toward the center of throat with very beautiful markings on three lower petals.

La Paloma (Dusinberre-Gove). The brightest, clearest orange we have ever seen Large, 50c; Medium, 35c; Small, 20c; Blts., 25 for $\$ 1.00$.

in a glad. Tall spike and several flowers open at the same time. Fine propagator and has all the qualities of a good commercial glad.

Large, $\$ 5.00$; Blts., 2 for $\$ 1.00$.

Longfellow (Prestgard). La France pink. A pleasing color. Many large, wide open flowers. Tall, slender, wiry stem.

Large, 25c; Medium, 15c; Small, 10c; B1ts., 50 for $\$ 1.00$.

Lorice $(K e m p)$. Salmon overlaid with scarlet. A fine flower and a strong grower. Large, 25c; Medium, 15c; Small, 10c.

Loyalty (Austin). A new deep yellow with large flowers and ruffled petals. One of the very best.

Large, $\$ 1.50$; Medium, $\$ 1.00$; Small, 50c; Blts., 10 for $\$ 1.00$. 
Mammoth White $(U . B . C o$.$) . Pure white with faint cream in the throat. Huge$ blossoms closely set on a straight spike. One of the largest of all glads. Large, \$4.00; Medium, \$3.00; Small, \$2.00; B1ts., 3 for $\$ 1.00$.

Marnia $(K e m p)$. A beautiful live golden orange. A very fine showy variety. Large, 15c; Medium, 10c.

Marmora (Errey). A magnificent flower of greyish lavender color, with an old rose blotch. Very large flowers, many open at a time, iand the last floret as large as the first to open. Nothing like it.

Large, \$1.00; Medium, 50c; Small, 25c; B1ts., 50 for $\$ 1.00$.

Mary Frey (Gelser). Lavender pink similar to Mrs. F. C. Peters, but has a warmer shade. Three to four weeks earlier than Peters. Stem 1 all and willowy. Fine propagator.

Large, 25c; Medium, 15c; Small, 10c.

Millionaire (Kunderd). Rich velvety crimson with a cream throat blotch. A striking flower.

Large, 50c; Medi11m, 30c; Small, 15c; B1ts., 15 for $\$ 1.00$.

Minuet (Coleman). A very beautiful shade of delicate clear lavender. Four to six open at a time. Large flowers and a very strong, sturdy grower. The finest clear lavender ever produced. In a class by itself.

Large, 75c; Medium, 50c; Small, 25c; B1ts., 25 for $\$ 1.00$.

Mother Machree (Stevens). This is so different from any other glad that a description is almost impossible. Vigorous grower, tall, straight spike with plenty of bloom, six or eight open at one time, facing and arrangement of the blooms excellent. The color has been described as a light grey with a few flashes of grenadine pink. To me it looks like a beautiful sunset. A truly remarkable variety and an excellent keeper as a cut flower.

IVe are offering this variety in six sizes:

No. $1, \$ 25.00$; No. 2 , $\$ 20.00$; No. 3 , $\$ 15.00$; No. 4 , $\$ 10.00$; No. 5 , $\$ 7.50$; No. $6, \$ 5.00$. B1ts., $\$ 1.00$ each.

Mrs. Calvin Coolidge (Kunderd). A superb grandiflora prim. of a soft salmon color with a pale yellow throat. Beautiful flower with frilled edges. One of the finest.

Large, $\$ 1.00$; Medium, 50c; Small, 25c; B1ts., 10 for $\$ 1.00$.

Mrs. F. C. Hornberger (Hornberger). One of the best of all pure white varieties. Won the championship cup for the best three spikes in the Boston Show, also received first on pure white.

Large, 35c; Medium, 25c; Small, 15c; Blts., 50 for $\$ 1.00$.

Mrs. Leon Douglas (Diener). Ground color begonia rose striped with flame and brilliant scarlet. Lip pale yellow, slightly speckled with ruby. The flowers are very large and well open. Spikes are extra long. A fine variety. The giant of the "Glad World."

Large, $15 \mathrm{c}$.

Mrs. P. W. Sisson (Coleman). A beautiful clear cameo pink. Tall, strong spike, very large flower, and many open at a time.

Large, 35c; Medium, 25c; Small, 10c; B1ts., 50 for $\$ 1.00$.

Mrs. T. Rattray (Rattray). Large bright rose flowers, many open at once. Fine exhibition variety. Very scarce.

Large, \$3.00.

Mrs. Van Konynenburg (Pfitier). Tall, clear light blue. We believe this the best clear light blue on the market. A good propagator and in great demand. Large, 50c; Medium, 25c; Small, 15c; Blts., 50 for $\$ 1.00$.

Mrs. S. A. Errey (Errey). A magnificent exhibition spike of a bright orange red with deeper blotch. For best effect should be cut when the first bud opens, and open in water.

Large, $\$ 4.00$; Medium, $\$ 3.00$; Small, $\$ 2.00$; B1ts., 2 for $\$ 1.00$.

Nancy Hanks (Salbach). Rich apricot to orange pink with grenadine tongue. Six or more flowers open at one time, fine placement and substance. Large, 25s; Medium, 15c; B1ts., 100 for $\$ 1.00$.

Orchid Lady (Spencer). A large, loose fiower of large lavender, striped deeper. Early and a good propagator.

Large, 75c; Medium, 50c; Small, 25c; Blts., 25 for $\$ 1.00$.

Paul Deschanel (Lemoine). This French variety has the same shape flower and same general formation of Emile Aubrun and Marmora. In color a bright rose with a large blotch of a deeper shade. Fine exhibition spike and good grower. One of the best. Large, \$1.50; Medium, \$1.00; Small, 75c. 
Pearl of California (Kingsley). Now too well known to require much description (see illustration). Clear La France pink blending to a rosy white throat. In some soils it is striped with a deeper color, making it look even richer. Awarded first prize as best spike at the 1929 show at Palace Hotel, San Francisco, also first for best variety originated in California. ' Awarded first and second prizes as best pink at the A. G. S. show in Springfield, I1l., 1929. A1so a winner at Boston, Mass.

Large, 75c; Medium, 50c; Small, 25c; Blts., 20 for $\$ 1.00$.

Persia. The black gladiolus. Large, 25c; Medium, 15c.

Pfitzer's Triumph (Pfitzer). Salmon Orange flower of a softer color than Dr. Bennett. Immense blooms well expanded and well placed. A very fine red and in great demand.

Large, 75c; Medium, 50c; Small, 25c; Blts., 25 for $\$ 1.00$.

Pride of Portland (Ellis). Clear begonia rose with cream blotch. Large, \$1.50; Medium, \$1.00; Small, 50c; Blts., 25 for $\$ 1.00$.

Primrose Princess (Salbach). Large clear primrose yellow, lower petals darker. Tall plant. Long spikes of well placed blooms. Several open at a time.

Large, 75c; Medium, 50c; Small, 25c; Blts., 30 for $\$ 1.00$.

Purest of All (Pfitzer). The whitest white. Small bulbs, 25c.

Purple Glory (Kunderd). Tyrianrose, suffused amaranth-purple; slightly flaked; a very dark, velvetypurple in throat.

Large, 15c.

Purple Queen (Kunderd). A deep violet purple glad with a darker throat. A very good color and a good grower.

Large, 25c; Medium, 15c; B1ts., 50 for $\$ 1.00$.

Queen Mary (Salbach). A lovely ruffled flower of strawberry pink with a scarlet heart set into the pale orange yellow of the lower petals. Good substance. Good grower and rapid multiplier.

Large, 50c; Medium, 25c; Small, 15c; B1ts., 25 for $\$ 1.00$.

Red Glory (Piper). A tall, vigorous plant. Deep red flowers of heary substance and intensely ruffled. Very good.

Large, \$1.00; Medium, 50c; Small, 35c.

Red Tornado (Eliis). Strong growing, brilliant red with a darker throat, very velvety.

Large, $\$ 2.00$; Medium, $\$ 1.00$; Small, 50c; B1ts., 15 for $\$ 1.00$.

Rippling Waters (Ellis). Fine exhibition spike of soft cream, tinted pink. Very attractive.

Large, \$1.00; Medium, 75c; Small, 50c; Blts., 25 for $\$ 1.00$.

Rita Beck (Fisher). Clear shell pink with scarlet lines on the lip. Very large flowers of good substance. Blooms late. This is an outstanding light pink glad. Large, 75c; Medium, 50c; Small, 25c; B1ts., 25 for $\$ 1.00$. 
Royal Lavender (Schlcider-Gove). A rich rose lavender which should become a favorite when better known. Very attractive.

Large, \$1.50; Meclium, \$1.00.

Royal Purple (Kunderd). A large bloom of rich royal purple with a slight red cast. Spike tall and slender. A very distinctive color. Large, 25c.

Salbach's Pink (Salbach). Large wide open geranium pink flower with soft carmine tongue and throat markings. Long graceful spike with six to eight flowers open at once. A sure comer.

Large, \$7.50; Medium, \$5.00; Small, \$2.00; Blts., 3 for $\$ 1.00$.

Saraband (Salbach). Very large wide open flower of rich velvety bordeaux with straw yellow blotch, feathered bordeaux. Fine placement, good substance. Tall. As rich as an Oriental rug.

Large, 25c; Medium, 15c; Blts., 50 for $\$ 1.00$.

scarlet Bedder (Salbach). Beautiful soft glowing scarlet, very distinct and beautiful prin.

Large, 35c; Medium, 25c; Small, 15c; Blts., 30 for $\$ 1.00$.

Sheba (Salbach). Very large, wide open jasper pink flowers on a tall spike. A splendid cut flower and a good propagator.

Large, 50c; Medium, 25c; Small, 15c; Blts., 30 for $\$ 1.00$.

Star of the Sea (Ellis). Beautiful peach red, brownish blotch tipped with yellow on lower petals: very large flower of great beauty.

Large, \$1.00; Medium, 50c; Small, 25c; Blts., 20 for $\$ 1.00$.

Sword of Mahomet (Ellis). An indescribable shade of brownish red with a greyish cast. Strong grower with immense spikes and numerous side spikes. An interesting oddity.

Large, 50c; Medium, 35c; Small, 25c; B1ts., 30 for $\$ 1.00$.

The Aristocrat (Bill). This is a true Aristocrat among the hundreds of good ones. Large, strong, massive spikes of most delicate coloring. A pale saffron pink flaked deep orange with cream throat and a very distinct violet feather.

Large, 25c; Medium, 15c; Small, 10c; B1ts., 25 for $\$ 1.00$.

The Orchid (Sprague). A decided novelty. Lavender-pink upon a paler flushed frosted surface. Edges beautifully lacinated and ruffled. Looks so much like an orchid that anyone would say the name is most fitting.

Large, 25c; Medium, 15c; Small, 10c; B1ts., 50 for $\$ 1.00$.

Veilchenblau (Europe). The finest of the dark blues. Large and vigorous and in great demand.

Large, 50c; Medium, 30c; Small, 20c; B1ts., 20 for $\$ 1.00$.

W. H. Phipps (Diener). A salmon pink flower, lighter toward the center. Lower petals faintly striped and speckled with ruby. Enormously large flowers, with 12 to 15 open at a time. Magnificent.

Large, 20c; Medium, 10c; Blts., 20 for $\$ 1.00$.

Primulinus Species--The Maid of the Mist found under Victoria Falls (Africa). One of the parents of all the prims. Small flowers peculiarly hooded of a pure primrose yellow. Tery graceful and keeps blooning all summer if given plenty of moisture.

20 cents each.

\section{... A Fiew Inexpensive Glads...}

\section{P After the Name Denotes Primulinus Hybrid}

Arlon (P), salmon, 10c

Break O' Day, pink, 10c

Byron L. Smith, lavender, 10c

Carbone, J. A., orange, $10 \mathrm{c}$

Cardinal Prince, red, $15 \mathrm{c}$

Crimson Glow, red, 10c

Cygnus (P), cream-pink, 10c

Dr. F. E. Bennett, scarlet, 15c

Eldora, light pink, 15c

Fern Kyle, cream, 10c

Giant Nymph, pink, 10c

Liberty (P), pink and yellow, 10c

Los Angeles, pink, $10 \mathrm{c}$
Madison Cooper, red, $10 \mathrm{c}$

Marietta, salmon, 10c

Mrs. Dr. Norton, pink, 10c

Mrs. F. C. Peters, lavender, 10c

Mrs. Leon Douglas, salmon, 15c

Myra (P), salmon pink, 10c

Orange Queen (P), 10c

Primevere (P), yellow, 10c

Richard Diener, pink, 10c

Rose Glory, rose, 10c

Rose Mist, (P), rose, $15 \mathrm{c}$

Souvenir (P), yellow, 10c

Zenobia (P), orange, $10 \mathrm{c}$ 


\section{... Gladiolus in Mixture...}

Unexcelled value in these collections; order generously of these for your cutting garden. They also make fine gifts for your friends.

We will send these prepaid and, in case of a gift, enclose your personal card.

California Rainbow Mixture. All the colors of the rainbow. This is a real mixture, no two alike, high class named varieties but not labeled.

Assorted blooming size bulbs, 25 for $\$ 2.00$.

Kingsley's Prim. Mixture. This is a hand-made mixture of Primulinus Hybrids and is characteristic of the best of that type. They range in color from tine clearest primrose, through apricot, buff, orange, pink, rich deep rose, and red. Cannot be excelled for house decoration and very effective in the garden.

Assorted blooming size bulbs, 25 for $\$ 1.00$.

Accidental Mixture. We do not know what this mixture consists of; there are probably many of our choicest glads in it, as every bulb that falls to the floor in the course of cleaning and grading is put in this mixture. We cannot guarantee that it is a "balanced" mixture, but we do guarantee that it is of the same high quality which characterizes all our stock.

One dozen bulbs for $\$ 1.00$.

\section{... Dahlias...}

As we are specializing in Gladiolus, the first qualification we ask of a Dahlia is, naturally, the keeping quality as a cut flower.

Therefore you will find in this list most of the best varieties, regardless of price.

Dahlias are ready for shipping about March 15.

Prices are quoted for single tuber.

AC signifies American Cactus; C, Cactus; D, decorative; H. C., hybrid Cactus; P, Peony.

Pompons are listed separately.

Al Koran-D. A large amber yellow flower with wavy petals on a tall, strong stem. A very good general purpose dahlia. $\$ .75$

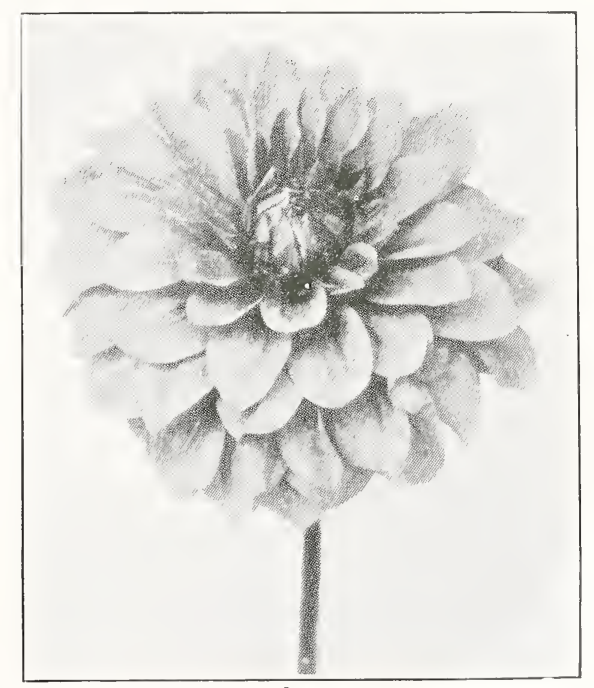

Amun Ra-D. An enormous flower of rich deep orange with coppery tints. A consistent prize winner ever since its introduction. We remember the first bloom "as big as a plate" exhibited in an exclusive San Francisco florist's

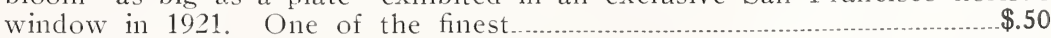

Black Jack-D. A very tall grower. Deep velvety maroon howers on perfect stems. Very striking......

$\$ 1.00$

Champagne-D. A fitting name, hard to describe; a sort of a pinkish orange buff color. Large, massive flowers on long rigid stems. A beauty _.........\$1.00

City of Portland-P. A pleasing shade of cool yellow. Flowers of good form on long stiff stems........ $\$ 1.00$

Delice-D. A pure pink flower which has become "the" standard cut flower $\$ .50$

Earle Williams-D. A splendid bi-color of brilliant crimson and white. Fine substance and strong straight stems

Ellinor Vandeveer-D. Large blooms of a glowing satiny pink, held high on exceptionally long stiff stems.

Francesca-D. A very large flower with long wavy petals. The color is a sort of dull rose, suffused violet and there are old gold markings on the petals. The long, strong stems carry the flowers to perfection. 
Gertrude Ederle-H.C. A soft primrose yellow, straight petaled hybrid cactus. Produces quantities of very large flowers on stiff stems. Exceptionally good keeper

Jane Cowl-D. An immense bloom of a glistening shade of bronzy buff and old gold, deepening toward the center. Perfect stems and foliage. This was one of the sensations of the principal shows last summer. One of the very best.

Jersey's Beauty-D. Probably the most popular dahlia ever introduced. The color is a true pink, the size of the flower is just right, the substance is fine, the stems are long and strong. Altogether a very nearly perfect variety.

$\$ .75$

Jersey's King-D. A begonia rose flower with broad petals rounded at the tips.

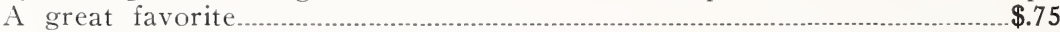

Karma-D. A beautiful clear amaranth pink of medium height. Exceptionally

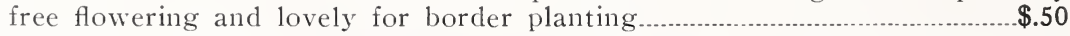

King Tut-D. Extra large blossoms of rich, dark, velvety crimson burgundy. An

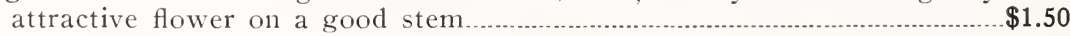

Kitty Dunlap-D. A fine large flower of American Beauty rose, on long stiff

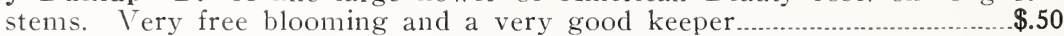

La Favorita-H. C. Flaming orange of good size, and an abundance of blooms

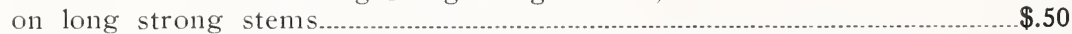

Mariposa-D. Large flowers of delicate rose pink, with very good centers. One of the finest for cutting. Recommended for warm climates.....................\$.75

Meadow Lark-D. Fine, large flowers with shadings of buff and straw. Very

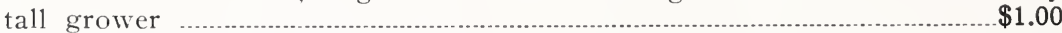

Mrs. Carl Salbach-D. One of the most dependable of all dahlias. Symmetrical flowers of a clear mallow pink, borne on long stout stems. Beautiful........\$.50

Mrs. I. de Ver Warner-D. Very large, mauve pink flowers of finest form, on

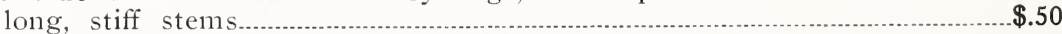

Nichu-H. C. Very large incurved sulphur yellow with a perfect closed center, on perfect stems. Prolific bloomer

Oriole, The-P. A striking combination of burnt orange, red and yellow, with many of the flowers shading to white at the tips. Numerous large blossoms on very good stems.

$\$ .50$

Pride of California-D. The best of the red decoratives. Strong grower and free bloomer. Has good color, large flowers, strong stems, and is a fine

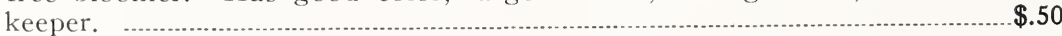

Regal-D. One of the very finest. A rich bronze shade, heavily suffused with old rose and shading to gold at the center. Excellent form and very good stems. Plants medium height, blooming profusely the entire season.............. $\$ 10.00$

Regent-A. C. A Tyrian pink flower, shading lighter in the center, which is entirely hidden by the incurving petals. Good size, pleasing color and fine stems.

$\$ 1.00$

Salbach's White-D. A most beautiful ivory white dahlia of perfect form. Very good substance and excellent stems. The best white we know of............\$3.00

Tommy Atkins-D. A large dazzling scarlet dahlia of fine form held on long straight stems. A very unusual color and a prolific bloomer _............... $\$ 1.00$

Union Jack. A very unique English single, with petals evenly striped red and white. The low growing bushes are excellent for massing _.................\$.75

Wizard of $\mathrm{Oz}-\mathrm{D}$. Exceptionally large blooms of salmon rose, shading to amber at the center. Very good stems.

$\$ 1.50$

\section{... Dahlia Collections ...}

We make up these collections of assorted colors, in order to give you variety. Each kind will be labeled separately.

6 varieties, all different, our selection, value $\$ 3.00$ or over.

10 varieties, all different, our selection, value $\$ 7.50$ or over

12 varieties, of pompons, all different, your selection for

12 varieties, of pompons, all different, our selection for. 


\section{... Pompon Dahlias...}

Pompon Dahlias are great favorites with the florists, as they lend themselves to decorations of all kinds. They are also fine in the garden, blooming as they do all summer. We pride ourselves on our collection of pompons which, we believe, is second to none.

Amber Queen-Rich golden bronze of fine form ...................................... 50c

Atom-Very small orange, free bloomer

Bacchus-Bright scarlet .......... 50c

Daisy-Amber shading to apricot

Dee-Dee-Good lavender with strong, perfect stems...................................... 50c

Douglas Tucker-Golden yellow, crimson center

Eva Salbach-Beautiful deep red..............................................................

Girlie - Beautiful pure rosy lilac

Glow-Light old rose to coral. A great favorite

Hazel Dell-Clear pink, cerise edge

Joe Fette-Smallest white and best

Lilias-Lovely cream, suffused pinkish mauve................................................ 50c

Little David-Deepest orange. Free bloomer, one of the best ......................... 50c

Little Donald-Garnet, very good _.............. 50c

Little Edith-Very small golden yellow, tipped red

Lolita-Rich yellow with brownish red center. Very fine............................. 50c

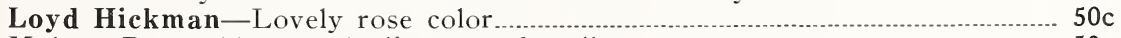

Major-Deep old rose, shading to soft yellow

Mars-Brilliant orange red...

Nellie Fraser-White ground, tipped pinkish lavender.................................... 50c

Phyllis-Yellow, heavily shaded cherry rose; extra good .................................. 50c

Phoebe-Orange and red. Very fine -

Rosea-Deep lilac, small

Sammy-Yellow, tipped bronze

Sunny Daybreak-Apricot, edged red. Fine form -

Unice-Lavender, white shading _.

Yellow Gem-Finest yellow. Very free bloomer.................................... 50c

Pompon dahlias should be planted as soon as received, as the tubers are small and the eyes are apt to dry out if left exposed to the air for any length of time.

\section{... Irises...}

Iris, the rainbow flower. All the colors of the rainbow seem to softly blend in these beautiful flowers. Irises are inexpensive, extremely hardy, and may be grown under a great variety of conditions with the minimum care.

Irises should be planted shallow, the rhizomes or fleshy part of the root should beljust under the surface of the ground.

If your location is a low spot where the water will stand, it is advisable to make raised beds, so that the water can not stand around the roots. Good drainage is necessary. If the soil is sour, an application of hydrated lime is advisable. Never use manure.

Our prices are based on strong, single divisions. We strongly advise planting in July and August, the plants are not then as large or well developed as they are in the Fall, but it is to your advantage to have the plants make their growth in your garden rather than our own.

$S$ refers to the three upstanding petals-the standards.

$\mathrm{F}$ to the three lower petals-the falls.

Alcazar-S. Light bluish violet, F. deep purple, bronze veined throat. Tall,

large flowered and vigorous

Ambassadeur-S. Bronzy violet, F. dark velvety maroon of fine substance, rich

orange beard. Late blooming. One of the very best................... 50c

Amber. Very striking, pure deep yellow with prominent reddish gold beard.

Tall, strong grower. 
Aphrodite. A rery beautiful clear riolet-pink self, with no veinings. The best of its color.

Ballerine. A splendid iris, with broad, waved petals. S. clear light blue violet. F. deeper blue violet. Very large blooms well placed on tall, branched stalks

Caroline Stringer. Large, delicately flushed rose flower of exceptional substance

$\$ 3.00$

Clement Desormes. A bright, deep red pink flower, with conspicuous orange beard

Conquistador. The tallest iris in our garden; we have had it 62 inches without any particular care and, in spite of its height, it does not fall over in a strong wind. Tery large deep mauve to light violet flower. Tall, broad foliage

$50 \mathrm{c}$

Coronado. A glorious flower with flaring falls. S. lavender. F. red purple, paling to lavender margings; beard and style arm golden............. \$1.50

Corcnation. A large, new golden yellow self. Standards, falls, beard and stamen are golden yellow. One of the very best of the new yellows........ \$5.00

Dream. A very lovely orchid like, crinkled rose pink iris, with orange beard. Perfect form and long blooming season.......................................... 40

Eldorado. S. yellowish bronze. F. bright violet purple. Very distinct and striking. Fine for massing …… 25c

Glowing Embers. S. light brownish lavender. F. very rich velvety pansy purple with orange beard. A rich, heavy flower on a well branched stem.... $\$ 3.00$

Gold Imperial. A yellow self of a wonderful bright color. S. and F. empire to lemon-chrome yellow with orange beard.................................... $\$ 3.00$

Hidalgo. A very large lavender self, which, under electric lights, shows as a beautiful orchid pink. Tall, upstanding and very good for California. Very

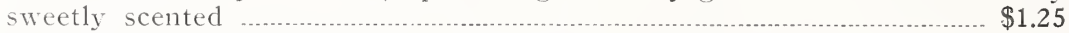

Iris King. S. golden yellow. F. rich maroon red bordered yellow. Tery popular and frequently blooms in the Fall in California ……. $25 \mathrm{c}$

Isoline. S. silvery lilac, flushed yellow. F. purplish old rose. Very large flowers, beautiful and distinct....... $35 \mathrm{c}$

Jeanne d'Arc. A dainty white flower with light lavender frilled edges. Fragrant

Lady Foster. A fine lavender blue iris. Flowers very large and of good substance. Often blooms, for us, in the late Fall …...... 40 c

Lent A. Williamson. S. very broad, campanula violet. F. broad and drooping, velvety violet-purple with yellow beard. Large flowers on stout stems... 35c

Leverrier. S. Chinese violet. F. pansy violet, general effect light rose red. Large, fragrant flowers on tall, widely branched stalks...................... $\$ 1.00$

Madame Chereau. An old favorite. White with wide, frilled border of clear blue.

$25 \mathrm{c}$

Madame Durrand. An irrisdescent buff, flushed with lilac and amber. Large flowers on tall, well branched stems. Should be protected from strong winds

$\$ 1.75$

Magnifica. Huge flowers. S. light violet blue. F. red violet. A grand novelty, with us a vigorous grower. Early ...

Ma Mie. S. and F. clear white, frilled violet-blue. One of the best of the "embroidered" kinds

Mary Gibson. S. light rose, suffused buff. F. deeper rose, slightly suffused violet and buffed with bronze markings on a cream base. Orange beard. Flowers of excellent substance on tall stems ................................... \$4.00

Micheline Charraire. Pure white, with golden yellow beard and bronze-gold pencilings at the throat. New $\$ 8.50$

Mildred Presby. S. white. F. rich dark velvety pansy violet with a narrow edge of lavender white.

$\$ 1.50$

Mother Machree. The color is changeable grey and blue. Yellow beard and throat markings. Far more beautiful and more delicate in coloring than Quaker Lady. Wonderful cut flower.

$\$ 2.50$

Mother of Pearl. S. and F. pale bluish lavender with a faint creamy undertone. Jarge flowers of perfect form, with the lustre and irridescence of a sea shell. Tall, vigorous and a profuse bloomer. Each 40 c, three for.... $\$ 1.00$

Nancy Orne. A purple rose flower suffused with yellow, giving the effect of a lovely fawn pink. Stalks low and well branched. Very free flowering. Each 30c, three for. 
Ochracea. This flower was named Ochracea Cerulea by its originator, M. Denis Later in England it was renamed Sunset, but is now recognized by the American Iris Society as Ochracea. S. real old gold, finely arched and of great substance. F. coppery yellow, heavily suffused blue violet and prominent yellow beard. Strong growing, free flowering and sweetly scented. The latest to bloom in our garden.

$\$ 1.00$

Opera. S. violet rose. F. rich velvety violet purple. Early and very beautiful.

$50 \mathrm{c}$

Pallida Foliis Variegatis. As the name implies this iris has variegated foliage, light green and cream. The stiff stems are evenly striped and carry a profusion of lavender blue flowers with a distinct orange blossom perfume. Very long blooming and has a real landscape value. Each $40 \mathrm{c}$, three for $\$ 1.00$

Perfection. S. light lavender violet. F. dark velvety violet. A dark rich flower, very floriferous, medium height. 25c, three for

Purple King. A deep purple iris which, in California, blooms most any time. If placed in a sheltered position will most always bloom for Christmas. Large flowers of good substance

Rameldo. Brownish petunia violet. Very unusual and perfectly hardy any-

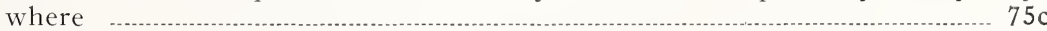

San Gabriel. A very large pinkish lavender of high excellence. Very early and long blooming. Branching and very graceful. No California garden should be without it ......-. \$1.25

Santa Barbara. The finest of the pure lavender blues. The size, substance, spreading horizontal falls, well branched stalks and the vigor of growth, entitle this beautiful iris to be rated with the highest....................... \$2.50

Simone Vaissiere. S. white shaded azure. F. brilliant aniline blue; throat veined gold and maroon on white base. Very beautiful

$\$ 2.00$

Souvenir de Mme. Gaudichau. S. Bradley's violet. F. brilliant blackish purple. An unusually dark velvety bicolor of fine shape and exceptional sub-

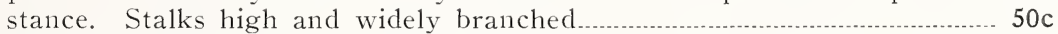

Sunset. See Ochracea.

Wedgewood. A rich, true blue self. Both S. and F. are a uniform color of Wedgewood blue shading to white at the base of the segments with a white beard. Probably the best of its color.

$\$ 3.50$

\section{... Various Beardless Irises...}

These irises are very desirable to plant along streams or around pools and ponds, and in the garden they make fine groups. They do best in moist rich soils, but will stand a summer rest and drying out. Do not give lime. Plant in late Fall, from October to December.

Aurea. Spuria type. Very tall plant with large full, deep golden yellow flowers, posed on the stems like huge butterflies $50 \mathrm{c}$

Dorothea K. Williamson. A hybrid of the American species Fulva and Foliosa. Large velvety flowers of the most vivid purple. This is one of the best beardless irises. Excellent for cutting..

Lord Wolseley. Not quite as tall as Aurea. S. rich violet. F. blue spotted yellow

Monnieri. A species close to Spuria. Very tall deep green foliage. Flowers large, clear lemon yellow. Fine for cutting.

Each, 50c, three for $\$ 1.00$, dozen for

Orientalis Gigantea (Ochroleuca). Fine white flowers with orange-yellow blotch, on very tall plants. Forms splendid clumps when established..... 25c

Perry's Blue. One of the very finest Siberian irises. Narrow, graceful foliage, and tall, slender stems, with handsome blue flowers. A clump of these in bloom on the edge of the pool is a lovely sight

Iris Foetidissima, or Gladwyn. Has fine evergreen foliage. Inconspicuous flowers, but in the late fall the seed pods open out to show rows of scarlet seeds of much beauty. Highly prized as winter decorations. An iris for mild climates 
After many years of comparative neglect Lilies, the favorites of old gardens, are again coming to the front.

Unlike most other garden subjects, Lilies happen in nature just as perfect or perhaps more so, as we see them in cultivation. There are very few hybrid Lilies and, while they may be different, they cannot be said to be improvements on the originals.

Plant in the Fall in well-drained soil, from six to eight inches deep. Place the bulb with about an inch of sand all around, and cover with soil made mellow by mixing with leaf mould, sand or peat moss. After planting, mulch the ground with well rotted manure, but do not have the manure touch the bulbs.

Lilies do not like to be disturbed, and should be allowed to grow in the same place for several years, when they will form fine clumps.

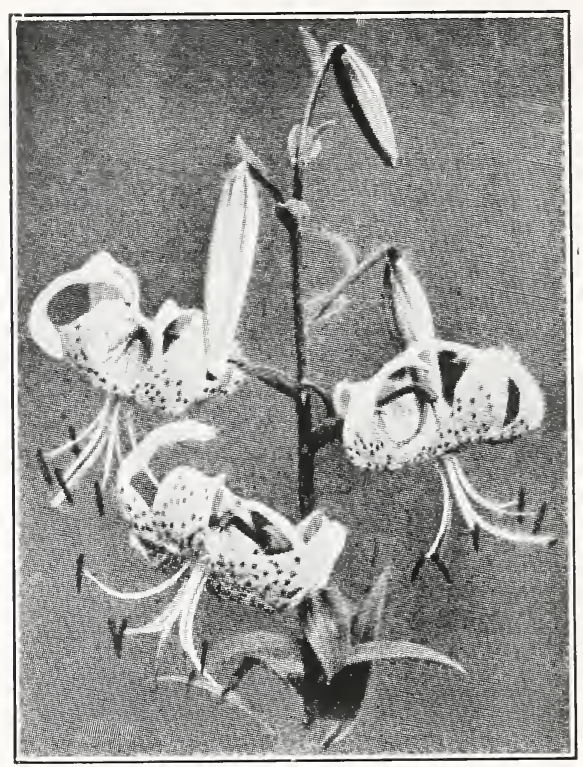

Elegans, or Cottage Lily is bright crimson, cup shaped and blooms in July. Should be planted six inches deep, any time after September 1 .................. 25c

Erabu Lily. An early flowering Easter Lily, said to be an improvement on Longiflorum, and much in demand. Plant six inches deep in September.. 50c

Henryi Lily. A very hardy and satisfactory variety for the garden. Recurved in form, yellow in color, fragrant and bearing from three to a dozen or more blooms to a stem. Plant in the Fall.

$50 \mathrm{c}$

Pardalinum. The Leopard lily, an attractive lily growing three feet high. Light yellow flowers tipped with crimson and recurved in shape. Plant six inches deep in the Fall..

$30 \mathrm{c}$

Regal Lily (Myriophyllum). The most popular of all the hardy garden lilies. A tube shaped lily, resembling the Easter Lily in form. The color is white, tinted pink on the outside, golden yellow throat and very fragrant.

Large, 50c; second blooming size.

$25 \mathrm{c}$

Roezli Lily. A native of Oregon. Resembles somewhat the Pardalinum, but lighter in color. Plant in the Fall six inches deep................................ 30 c

Tiger Lily. Probably the best known lily grown in American gardens. A tall sturdy lily, tawny red in color. Very hardy and the last to bloom in the summer

20c

Umbellatum Lily. A bright crimson lily which will grow anywhere. Very

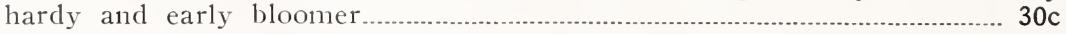

Washingtonianum or Mt. Hood Lily. A native of the mountainous sections of California and Oregon. A recurved lily of great beauty. Pure white, maturing first to pink and then to purple. Slow to become established, but may be grown on heavy clay soil, if not too wet.

$50 \mathrm{c}$

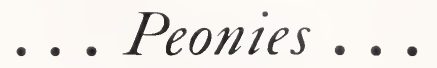

The herbaceous Peony is one of the fairest blooms in our gardens. Easy of cultivation, once established it lasts a lifetime. Peonies should be planted in September, October and November. In California it is best to plant after the first heavy rains, for then the ground is in just the right condition. 
Any good garden soil, deeply plowed or spaded, will produce good Peonies, but a rich black loam is best. Do not get manure in contact with roots, crown or stems, but a handful of bone meal mixed with the ground is beneficial. Plant so that the large eyes or buds are no more than two inches under the surface, after the ground has settled. If planted too deep, Peonies will not bloom.

Here, in California, it is important to water the plants through the summer, to enable them to form the new buds for the next season.

A coarse mulch of peat moss, leaves or even chopped straw around the plants will prevent the crown from burning and will help hold the moisture.

We offer here a select list of Peonies which will do well in any part of the country and which, in addition, have been thoroughly tested under California conditions.

We send out standard divisions of three eyes or over; in many instances we send out one year plants, that is, small divisions which have been grown one year in our garden and have formed new eyes and the new young roots which will be ready to take a hold as soon as transplanted.

Ben Franklin. Crimson-red semi-rose type flowers with golden stamen, on very tall, erect stems. Medium early, fine for cutting .............................. \$1.00

Cathedral. Japanese type. Deep pink flower with golden yellow center. Good.

$\$ 3.00$

Couronne d'or. White. Large, rose type flowers with a ring of yellow stamen surrounding a center tuft of white petals, often tipped with carmine. A late bloomer

$\$ 1.00$

Frances Willard. Creamy white. Large flower with cup shaped center, showing a few golden stamens. Very fragrant. A superb variety. Listed among the twenty-five world's best peonies......................................................... \$2.00

Grandiflora. (Richardson's). Shell pink. Immense flat flower of the rose type, with fine lacy petals. Quite fragrant. The latest to bloom in our garden.

Karl Rosenfield. Rich crimson. Large rose type. Tall, strong plant. Midseason.

$\$ 1.00$

Lafayette. A rose type flower of a rare shade of pink deeper toward the center. The large flowers are well carried on tall stems. This variety is a very good cut flower, also a good landscape peony. In the Spring, and until after the blooming season, the foliage is a bright purplish red. Midseason........... \$1.00

Marie Crousse. A delicately shaded shell pink of exquisite beauty. Large flowers on long, strong stems. Fragrant

Mary Brand. One of the very best double red Peonies. Fine rose type of per-

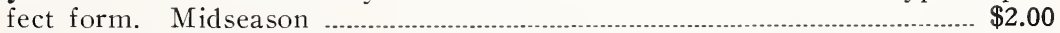

Monsieur Jules Elie. The most spectacular of the pink Peonies. Enormous flowers of silvery pink, very much like a huge chrysanthemum. Delightfully fragrant. One of the best show flowers. No garden should be with-

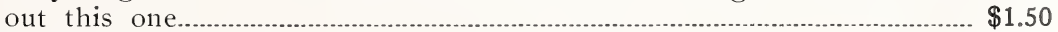

Nellie. Beautiful single Peony. The pink petals surround a prominent tuft of

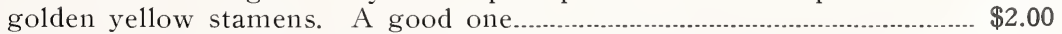

Primevere. Cream guard petals and sulphur yellow centers. Will hold its delightful color if taken indoors as the first petals unfold. Profuse bloomer and fragrant ............ \$2.00

Reine Hortense. (syn. President Taft). Semi-rose type. Very large soft pink flower, with crimson flecked center. Fragrant.............................. \$2.50

Richard Carvel. Flowers of a beautiful bright ruby red. Very fragrant, a rare quality in a red Peony. Lasts a long time in the garden and does not fade.

Ruth Brand. A very large hydrangea pink bloom of a perfect bomb shape A

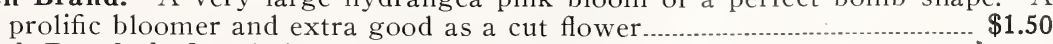

Sarah Bernhahrdt. Soft apple blossom pink blooms of large size, forming huge

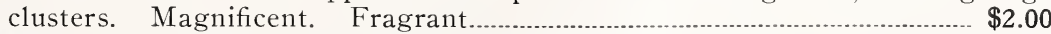

Solange. The color of this variety is very hard to describe. A deep cream, tinged with amber, and with a touch of salmon pink glowing from its heart. A beauty, and very rare. Must be thoroughly established to be at its best.

Therese. Satiny pink. Rose type of very large size. Erect, strong and free

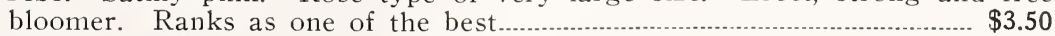

Tourangelle. Creamy white overlaid with shades of delicate salmon and La France rose. Large, flat rose type. Strong grower and free bloomer. One of the very best. 


\section{... Culture of Dahlias...}

Prepare the dahlia plot in the Fall, if possible, by spading deep and learing rough. If the soil is thin, work in barnyard manure or other fertilizer at this time. Spade again in the Spring.

Plant from April to June, according to climatic conditions.

Dig the holes twelve to eighteen inches deep, refilling to within six inches of the surface. If the drainage is poor, mix a shovel full of sand or wood ashes with the loose soil in the bottom of the hole. Never use fertilizer at planting time.

Lay the tuber flat in the bottom of the hole, eye side up; drive a stake near the eye end and cover the tuber with three inches fo loose soil. Fill in the remaining three inches as the plant grows. Water only moderately till blooming time, but cultivate persistently.

When the dahlia begins to bloom, fertilizer may be applied and deep cultivation should cease. Water well at least twice a week where there are no summer rains. Disbudding will produce larger blooms.

\section{... Books for Better Gardens ...}

THE BOOK OF BULBS, by F. F. Rockwell. Will help you grow bulbs successfully for spring, summer, fall, and winter flowering, inside and outside your home. The information in this book tells, and its pictures show how to grow 70 different bulbous plants including tulips, daffodils, hyacinths, lilies, gladiolus, dahlias, peonies, irises, begonias, cannas, bloodroots, and dozens of others. Recommended as the most complete and newest guide to bulb growing. 187 illustrations, 264 pages.

$\$ 3.00$

DAHLIAS, by F. F. Rockwell. Learn to know the different types of dahlias and their uses in your garden, how to plant and grow them, what fertilizers io use, how to control pests, how to harvest and store the tubers, grow for exhibition, and how to propagate and hybridize. Brief and practical. 65 illustrations. 80 pages.

$\$ 1.00$

(Lilies) GARDEN CINDERELLAS, by Helen M. Fox. Expert information on growing lilies by a gardener whose knowledge is proven by her own success. Tells the name of every lily in cultivation, its native home, season of blooming, propagation methods, and every other detail needed for success. Beautifully illustrated in color and half-tone. 51 illustrations, 269 pages.

$\$ 5.00$

IRISES, by F. F. Rockwell. A handy guide which will bring you success with irises and show new uses and effects possible in your garden. Describes the dwarf, early, German, Japanese, Siberian, water, crested, Spanish, English, Dutch and other types; tells the best soils; what fertilizers to use; how to plant; and what care is necessary. Tells how to propagate stock for your own use. $5+$ i1lustrations, 80 pages.

$\$ 1.00$

GLADIOLUS, by F. F. Rockwell. Recommended as "the best brief guide on gladiolus growing." It tells how to plant, fertilize, and cultivate; how to grow from seed or bulblets; how to harvest and cure; how to handle for cut flowers; and every other detail needed for success with this popular flower. 45 illustrations, 79 pages.

$\$ 1.00$

Notice-On all orders of gladiolus from our retail catalogue amounting to $\$ 10.00$ or over, we will give a copy of "Gladiolus" free if asked for at the time of ordering.

W. H. KINGSLEY, Hayward, California. 


\section{California Grown}

\section{Gladiolus}

Bulbs

When we consider that the Gladiolus is found in the natural state in Southern Europe, Asia Minor and Southern Africa, particularly in the coastal districts from Namaqualand to Natal, it seems quite natural that we should grow the best of glads in California where the climate approximates that of the Gladiolus native habitats. Nowhere in this country can better bulbs be produced.

Our bulbs have a long season in which to grow; they are not forced and matured before their time by torrid heat, as our particular section of California possesses the most equable climate in the United States.

We have no hurricanes to break the stems, no pelting rains to batter the flowers.

No rain from April to November, yet we have an abundance of water and, with the Skinner irrigation system, our glads receive just the proper amount of water, and just at the proper time to grow them to perfection.

When our bulbs are harvested they are fully matured, and our dry fall season permits of curing them in the mild sunshine.

Our storage facilities are of the best and, in the spring, when our bulbs reach you, they are vigorous and ready to grow.

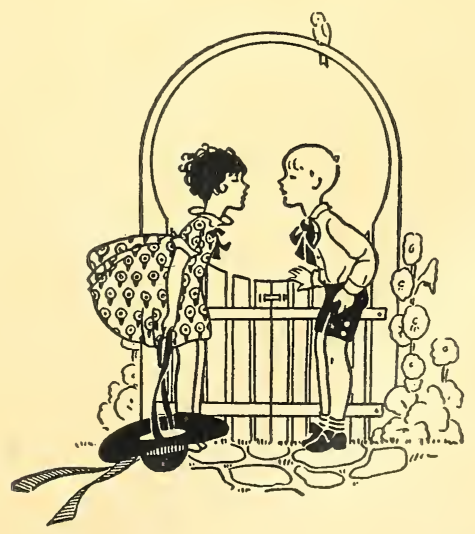




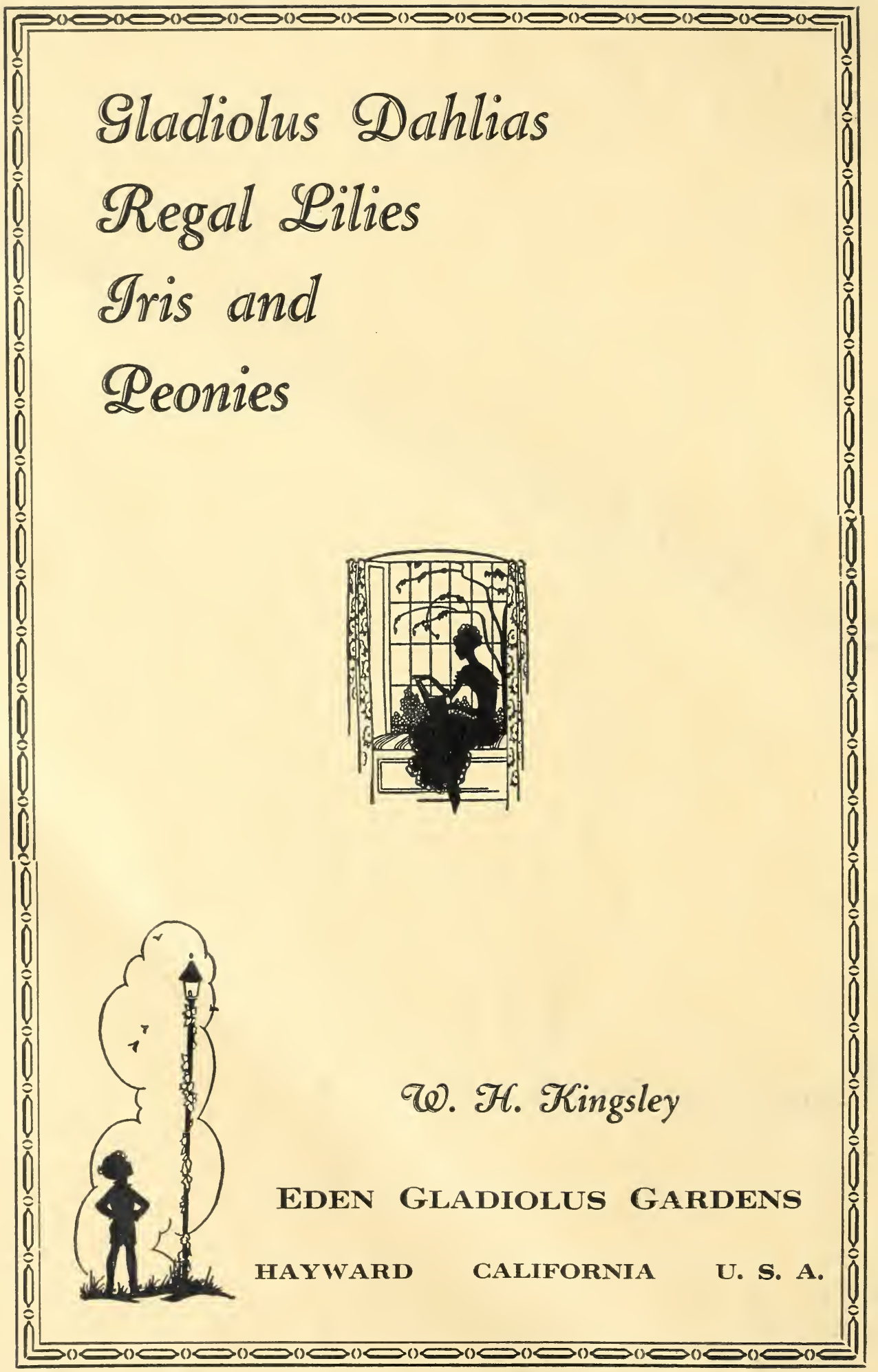

